\title{
Intravascular Papillary Endothelial Hyperplasia - Case Report
}

Liliana Gabriela Popa ${ }^{1,2}$, Manuela Simtea' , Irina Ahmed Salem³ ${ }^{3}$ Mara Madalina Mihai ${ }^{1,2}$, Cornelia Nitipir ${ }^{4,5}$, Calin Giurcaneanu ${ }^{1,2}$

\begin{abstract}
Intravascular papillary endothelial hyperplasia (IPEH) is an uncommon benign vascular lesion generated by an exaggerated endothelial proliferative response to vascular injury. It represents $2-4 \%$ of vascular tumors arising in the skin and soft tissue. Complete surgical excision is curative. Unfortunately, it is frequently confused with other vascular or soft tissue tumors. Therefore, promptly establishing the correct diagnosis helps avoid useless extensive investigations and overtreatment. We report a case of IPEH that developed on the skin of the lower left abdominal area in a 40-year-old female patient in the absence of previous local trauma or vascular anomalies.
\end{abstract}

Keywords: papillary endothelial hyperplasia, Masson's tumor, reactive process

\section{Rezumat}

Hiperplazia endotelială papilară intravasculară (IPEH) este o afecțiune vasculară benignă rară, generată de un răspuns proliferativ exagerat al celulelor endoteliale la o injurie vasculară. IPEH reprezintă $2-4 \%$ din tumorile vasculare ale pielii şi țesuturilor moi. Excizia chirurgicală completă este curativă. IPEH este adesea confundată cu alte tumori vasculare sau de țesuturi moi. Prin urmare, stabilirea promptă a diagnosticului corect este esențială pentru evitarea unor investigații extensive inutile si a unui tratament agresiv. Raportăm cazul unei paciente în vârstă de 40 de ani care a dezvoltat IPEH la nivelul tegumentului regiunii abdominale inferioare stângi în absența unui traumatism local anterior sau a unor anomalii vasculare preexistente.

Cuvinte cheie: hiperplazie endoteliala papilara, tumora Masson, proces reactiv

\section{INTRODUCTION}

Intravascular papillary endothelial hyperplasia (IPEH), first described by Pierre Masson in 1923 is an uncommon benign vascular lesion that involves the skin or the soft tissue ${ }^{1}$. IPEH represents $2-4 \%$ of vascular tumors arising in the skin and soft tissue ${ }^{2}$. It usually occurs in the fourth decade of life and has a slight predilection for the female gender ${ }^{3}$.
We report a case of IPEH that developed on the skin of the lower left abdominal area in a young female patient in the absence of previous trauma or vascular anomalies.

\section{CASE REPORT}

A 40-year-old woman was admitted to our clinic for the presence of a slowly enlarging cutaneous lesion lo-

\footnotetext{
' Department of Dermatology, Elias Emergency University Hospital, Bucharest, Romania

${ }^{2}$ Department of Dermatology, „Carol Davila" University of Medicine and Pharmacy, Bucharest, Romania

${ }^{3}$ Department of Pathology, Elias Emergency University Hospital, Bucharest, Romania

${ }^{4}$ Department of Oncology, Elias Emergency University Hospital, Bucharest, Romania

${ }^{5}$ Department of Oncology, "Carol Davila" University of Medicine and Pharmacy, Bucharest, Romania
}

\author{
Corresponding author. \\ Liliana Gabriela Popa, Department of Dermatology, Elias \\ Emergency University Hospital, No. 17 Marasti Bd, Bucharest, \\ Romania. \\ E-mail: lilidiaconu@yahoo.com
}


cated in the lower left abdominal area that had appeared 12 months earlier. The patient denied any previous trauma in that region. The lesion was a well circumscribed, $2 / 1 \mathrm{~cm}$, ovalar, bluish-purple, soft, non-pulsatile mass with an irregular surface. The overlying epidermis showed no changes (Figure 1). The patient complained of local tenderness on palpation. The general physical examination did not reveal other pathologic changes, except for the paleness of the skin and mucous membranes. The patient suffered from chronic moderate hyposideremic anemia, for which gastrointestinal and gynecologic causes had been excluded. She was under specific treatment prescribed by the haematologist.

The results of the laboratory tests were within normal limits, except for the moderate hyposideremic anemia.

The ultrasound examination showed an encapsulated 2.2/0.8 $\mathrm{cm}$ hypoechogenic mass located in the skin and subcutaneous tissue, suprajacent to the muscular fascia. Doppler evaluation showed peripheral vascularization, with minimal arterial and venous flows.

The lesion was surgically excised under local anesthesia. The histopathologic examination revealed a dermal tumor, partially delineated by fibro-hialine fascicles of variable thickness (a pseudocapsule), with multiple pseudocystic spaces of various dimensions occupied by erythrocytes and a homogenous eosinophilic material, that contain papillary structures lined by a single layer of flat/cubic epithelium surrounding a collagenized core (Figure 2). In several sites, the papillary projections fuse to form a network of anastomosing vessels. Immunohistochemistry studies showed positivity for CD31 and CD34 and negativity for D2-40. The histopathologic diagnosis was that of a reactive vascular proliferation - papillary endothelial hyperplasia (Masson's tumor).
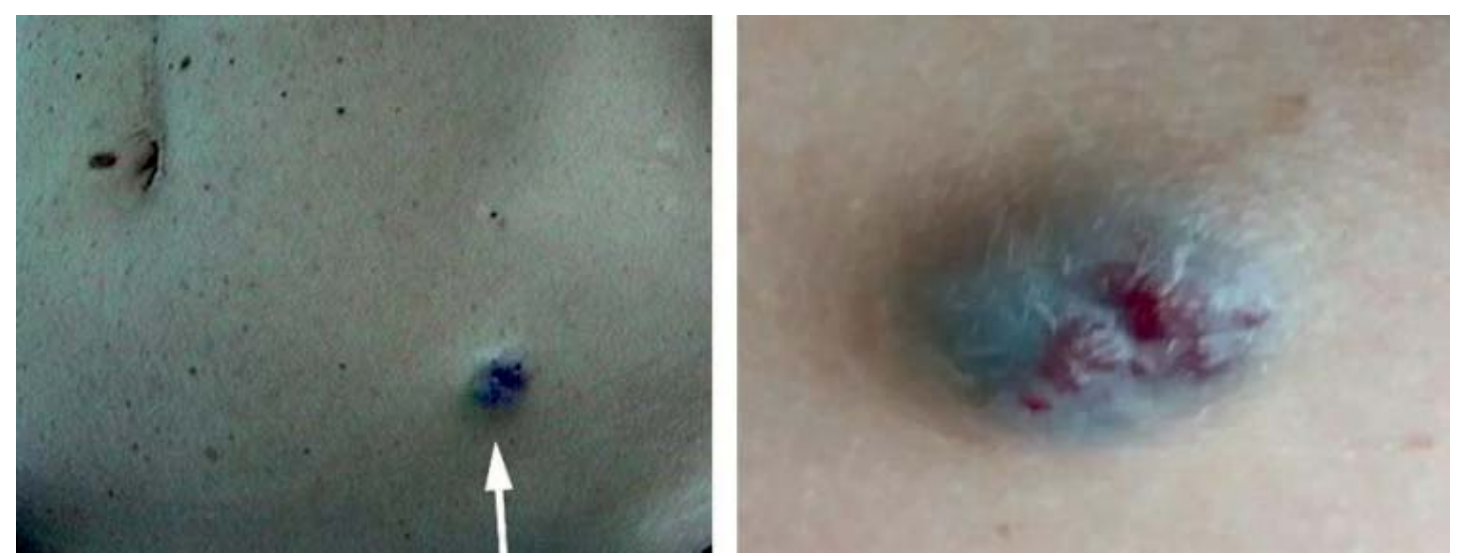

Figure 1. Well circumscribed, $2 / 1 \mathrm{~cm}$, ovalar, bluish-purple mass with an irregular surface located in the lower left abdominal area.
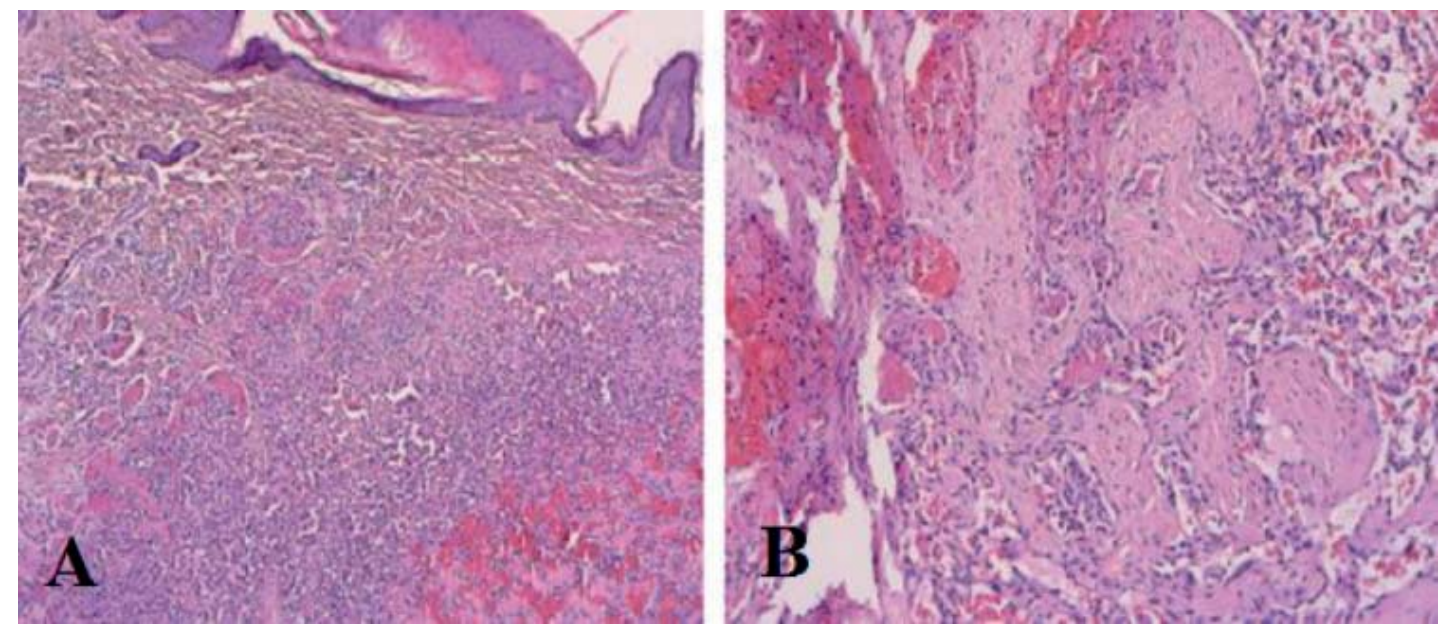

Figure 2. Haematoxylin \& eosin stain (A) magnification x 40, (B) magnification x 100 showing a dermal tumor characterized by the presence of a pseudocapsule and multiple pseudocystic spaces of various dimensions occupied by erythrocytes and a homogenous eosinophilic material, that contain papillary projections lined by a monolayer of flat/cubic epithelium surrounding a collagenized core. 
The patient had a favorable postoperative course and no sign of recurrence 6 months after surgery.

\section{DISCUSSION}

Although IPEH was initially considered a neoplastic process, nowadays its reactive nature is generally accepted $^{4}$. The etiology and pathogenic mechanisms of IPEH are not completely elucidated. It represents an exaggerated endothelial proliferative response to vascular injury ${ }^{5}$. Vascular trauma also generates thrombus formation, inflammation of the vessel wall and vascular stasis 6 . Many authors argue that thrombosis precedes endothelial proliferation ${ }^{7}$. In addition, fibroblast growth factor (FGF) released by the macrophages attracted at the injury site enhances the proliferation of endothelial cells. Subsequently, the endothelial cells themselves produce FGF and thus the process becomes self-sustained ${ }^{6}$. All these events lead to the formation of papillary projections within the vascular lumen ${ }^{5}$.

IPEH comprises three subtypes ${ }^{8}$. Primary or pure IPEH (type I), which develops within normal blood vessels (usually a vein) is the most frequently encountered. Secondary or mixed IPEH (type II) appears in pre-existing vascular conditions, such as varices, hemangiomas, lymphangiomas, pyogenic granulomas, haematomas, or arteriovenous malformations. The undetermined form (type III) is the rarest variant. It is an extravascular form, most often emerging in an organizing haematoma.

IPEH can arise anywhere on the body, but usually affects the head and neck area or the extremities ${ }^{9}$. Cases of IPEH located on the oral and lingual mucosa, in the gastrointestinal tract, liver, uterus, heart, intracranially, or in the orbital area have also been reported ${ }^{10}$. IPEH generally presents as a solitary well-circumscribed, round or ovoid, red or purple slow growing papule, nodule or soft-tissue mass, $0.2-5 \mathrm{~cm}$ in diameter ${ }^{11}$. Most lesions are asymptomatic, but some patients complain of local pain, especially when IPEH develops in a thrombosed varix ${ }^{10}$.

Preoperative imaging studies help differentiate IPEH from other soft tissue tumors. Ultrasonography shows a well-defined echogenic mass and can identify blood vessels related to $\mathrm{it}^{12}$. Doppler ultrasound detects venous and arterial flows within the lesion ${ }^{13}$. Magnetic resonance imaging can also provide useful information $^{3,13,14}$.

The histopathologic examination depicts the presence of papillary projections towards the lumen of a dilated and most frequently thrombosed blood vessel. The papillary projections display a hyalinized core covered by a monolayer of endothelial cells. The endothelial cells that line the papillary growths lack features seen in angiosarcomas, such as atypia, pleomorphism, or increased mitotic activity ${ }^{15}$. Immunohistochemistry studies show positivity for CD31, CD34, SMA, vimentin, and factor VIII-related antigen ${ }^{6}$. CD105 is another marker that can be useful in differentiating IPEH from angiosarcoma as it is positive in primary vascular neoplasms ${ }^{16}$.

It is sometimes challenging to differentiate IPEH from malignant vascular tumors, especially angiosarcoma, but also Kaposi's sarcoma and rare neoplasms like hemangiopericytoma, epithelioid hemangioendothelioma, and endovascular papillary angioendothelioma (Dabska tumor). The absence of atypia of the endothelial cells forming the lesion is a key differentiating feature from malignant vascular tumors. Moreover, angiosarcoma is rarely located intravascular, usually invading tissues outside the vessel. Solid areas and necrosis are frequent findings in angiosarcomas ${ }^{17}$. Benign conditions such as hemangiomas, lymphangiomas, hematomas, vascular malformations, pyogenic granulomas, angiolymphoid hyperplasias with eosinophilia, fibromas, traumatic neuromas, neurofibromas, schwannomas should also be considered in the differential diagnosis of IPEH.

IPEH is treated by complete surgical excision ${ }^{18}$. Wide surgical margins are not necessary. However, recurrences have been reported in the setting of incompletely surgically removed lesions ${ }^{19}$. Malignant transformation of IPEH has not been reported to date.

\section{CONCLUSIONS}

Physicians should be aware of this uncommon condition and include it in the differential diagnosis of vascular lesions. It is a benign tumor with a very good prognosis. Complete surgical excision is curative. Therefore, promptly establishing the correct diagnosis helps avoid useless extensive investigations and overtreatment.

\section{Compliance with ethics requirements:}

The authors declare no conflict of interest regarding this article.

The authors declare that all the procedures and experiments of this study respect the ethical standards in the Helsinki Declaration of 1975, as revised in 2008(5), as well as the national law. Informed consent was obtained from all the patients included in the study. 


\section{References}

1. Masson P. Hemangioendotheliome vegetant intra-vasculaire. Bull Soc Anat Paris 1923;93:517-523.

2. Clearkin KP, Enzinger FM. Intravascular papillary endothelial hyperplasia. Arch Pathol Lab Med 1976;100:441-441.

3. Clifford PD, Temple HT, Jorda M, et al. Intravascular papillary endothelial hyperplasia (Masson's tumor) presenting as a triceps mass. Skeletal Radiol 2004;33:421-425.

4. Henschen F. L'endovasculite proliférante thrombopoiétique dans la lésion vasculaire locale. Ann Anat Pathol 1932;9:113121.

5. Mahapatra QS, Sahai K, Malik A, Mani NS. Intravascular papillary endothelial hyperplasia: An unusual histopathological entity. Indian Dermatol Online J 2015;6:277-279.

6. Levere SM, Barsky SH, Meals RA. Intravascular papillary endothelial hyperplasia: a neoplastic "actor" representing an exaggerated attempt at recanalization mediated by basic fibroblast growth factor. J Hand Surg Am 1994;19:559-564.

7. Requena L, Sangueza OP. Cutaneous vascular proliferations. Part II. Hyperplasias and benign neoplasms. J Am Acad Dermatol 1997;37:887-919.

8. Hashimoto H, Daimaru Y, Enjoji M. Intravascular papillary endothelial hyperplasia: a clinicopathologic study of 91 cases. Am J Dermatopathol 1983;5:539-545.

9. Salyer WR, Salyer DC. Intravascular angiomatosis: Development and distinction from angiosarcoma. Cancer 1975;36:9951001.

10. Kakhandaki A, Dinesh US, Akash B. Intravascular Papillary Endothelial Hyperplasia as an unusual diagnosis for peri-orbital tumour - A case report. Indian J Ophthalmol 2018;66:163-165.

11. Espinosa A, Gonzalez J, García-Navas F. Intravascular papillary endothelial hyperplasia at foot level: a case report and literature review. J Foot Ankle Surg 2017;56:72-74
12. Tedla M, Bežová M, Biró C, et al. Intravascular papillary endothelial hyperplasia of larynx: case report and literature review of al head and neck cases. Otolaryngol Pol 2014;68:200-203.

13. Lysyy O, Schwartz I, Kolander Y, et al. Sonographic features of intravascular papillary endothelial hyperplasia (Masson's tumor) in the forearm. J Clin Ultrasound 2011;39:301-303.

14. Anthony SG, Mudgal CS, DeLaney TF, et al. Recurrent intravascular papillary endothelial hyperplasia of the right middle finger treated with radiation therapy. J Bone Joint Surg Br 2008;90:9597.

15. Gupta A, Chaturvedi S, Jha K, Nazir W. Intravascular Papillary Endothelial Hyperplasia Presenting as a Cystic Mass in the Scalp with Underlying Bone Involvement: A Rare Entitylnt J Appl Basic Med Res 2017;7:269-271.

16. Kim OH, Kim YM, Choo HJ, et al. Subcutaneous intravascular papillary endothelial hyperplasia: ultrasound features and pathological correlation. Skeletal Radiol. 2016;45:227-233.

17. Fasina O, Adeoye A, Akang E. Orbital intravascular papillary endothelial hyperplasia in a Nigerian child: A case report and review of the literature. J Med Case Rep 2012;6:300.

18. Park KK, Won YS, Yang JY, Choi CS, Han KY. Intravascular papillary endothelial hyperplasia (Masson tumor) of the skull: Case report and literature review. J Korean Neurosurg Soc 2012; $52: 52-54$

19. Avellino AM, Grant GA, Harris $A B$, et al. Recurrent intracranial Masson's vegetant intravascular hemangioendothelioma. Case report and review of the literature. J Neurosurg 1999;91:308312. 